Proc. Estonian Acad. Sci. Eng., 2006, 12, 3-1, 218-229

\title{
Critical values for the temperature factor to assess thermal bridges
}

\begin{abstract}
Targo Kalamees
Chair of Building Physics and Architecture, Tallinn University of Technology, Ehitajate tee 5, 19086 Tallinn, Estonia; kalamees@uninet.ee

Received 8 February 2006

Abstract. Climate analysis was conducted to determine the value for the temperature factor to be used for the design and infrared thermography inspections of Estonian dwellings to assess thermal bridges of the building envelope. For this analysis, data about the outdoor climate were retrieved from six weather stations, covering a 31-year period, from 1970 to 2000. For the indoor boundary conditions, the critical values from field measurements in detached houses were used. The aim was to avoid surface condensation and mould growth. Critical values of the temperature factor were calculated for different indoor humidity and temperature conditions. It was found that to avoid the mould growth on the thermal bridges in dwellings with a moisture excess of $+6 \mathrm{~g} / \mathrm{m}^{3}$ during the cold period and $+2.5 \mathrm{~g} / \mathrm{m}^{3}$ during the warm period (apartments with high occupancy or low ventilation) the spot temperature factor $f_{\mathrm{Rsi}}$ should be greater than 0.80 . For surface condensation, the limit value is $f_{\mathrm{Rsi}} \geq 0.70$. In dwellings with a moisture excess during the cold period $+4 \mathrm{~g} / \mathrm{m}^{3}$ and during the warm period $+1.5 \mathrm{~g} / \mathrm{m}^{3}$ (commonly detached houses: low occupancy and normal ventilation), to avoid the mould growth the $f_{\mathrm{Rsi}} \geq 0.65$ is needed and for surface condensation $f_{\mathrm{Rsi}} \geq 0.55$.
\end{abstract}

Key words: temperature factor, infrared thermography, thermal bridge.

\section{INTRODUCTION}

All the building envelopes have thermal bridges, that is locations where the thermal resistance is locally lower. Thermal bridges are caused mainly by geometrical or structural reasons. In cold climate, the assessment of thermal bridges is important for many reasons. Thermal bridges may lead to surface condensation, mould growth and staining of surfaces. Due to lower temperatures in the thermal bridge, higher relative humidity $(R H)$ occurs. While surface condensation starts at $R H=100 \%$, the limit value for $R H$ relative to the mould growth is above $75 \%$ and at $R H=80 \%$, growth conditions for nearly all species of mould fungi are good. Thermal bridges lead to an increase of heat losses. An 
increase in the thermal insulation level will increase the relative significance of the thermal bridges in the energy consumption of buildings. If large poorly insulated or uninsulated areas of the envelopes exist, the surfaces will be cold in winter and may cause thermal comfort problems due to cold draughts or radiation (in particular, asymmetric radiation).

For the inspection of thermal bridges with infrared thermography in real buildings, knowledge of the critical level of the thermal conductance of the thermal bridges is required. The International Energy Agency (IEA) $\left.{ }^{1}\right]$ has proposed to use the method of temperature factor to assess thermal bridges. It is the responsibility of each country to establish the design values of the temperature factor. The principle of the temperature factor is included also in the EN ISO 13788:2001 $\left[^{2}\right]$ standard. The temperature factor at the internal surface, $f_{\text {Rsi }}$, shows the relation of the total thermal resistance of the building envelope $R_{\mathrm{T}}\left(\mathrm{m}^{2} \cdot \mathrm{K} / \mathrm{W}\right)$ to the thermal resistance of the building envelope without the internal surface resistance $R_{\mathrm{si}}\left(\mathrm{m}^{2} \cdot \mathrm{K} / \mathrm{W}\right)$. It depends on the indoor and outdoor air temperatures $T_{\mathrm{i}}$ and $T_{\mathrm{e}}\left({ }^{\circ} \mathrm{C}\right)$ and on the temperature at the internal surface of the building envelope $T_{\mathrm{si}}$. In the literature the temperature factor is also referred to as the temperature ratio, temperature index, or condensation resistance factor. It is expressed as

$$
f_{\mathrm{Rsi}}=\frac{R_{\mathrm{T}}-R_{\mathrm{si}}}{R_{\mathrm{T}}}=\frac{T_{\mathrm{si}}-T_{\mathrm{e}}}{T_{\mathrm{i}}-T_{\mathrm{e}}} .
$$

Constant temperature factor assumes constant thermal resistance of the internal surface. In reality, the thermal resistance of the surface depends on the reciprocal value of the sum of convective $\left(\alpha_{\mathrm{c}}\right)$ and radiation $\left(\alpha_{\mathrm{r}}\right)$ heat transfer coefficients. The heat transfer coefficients can be calculated as $\left[{ }^{3}\right]$

$$
\begin{gathered}
\alpha_{\mathrm{c}}=2\left(T_{2}-T_{1}\right)^{0.25}, \mathrm{~W} /\left(\mathrm{m}^{2} \cdot \mathrm{K}\right), \\
\alpha_{\mathrm{r}}=\sigma \frac{1}{\frac{1}{\varepsilon_{1}}+\frac{1}{\varepsilon_{2}}+1} \cdot \frac{\left(T_{1}^{4}-T_{2}^{4}\right)}{\left(T_{1}-T_{2}\right)}, \mathrm{W} /\left(\mathrm{m}^{2} \cdot \mathrm{K}\right),
\end{gathered}
$$

where $\sigma$ is the Stefan-Boltzmann constant, $\mathrm{W} /\left(\mathrm{m}^{2} \cdot \mathrm{K}^{4}\right), \varepsilon_{1}$ and $\varepsilon_{2}$ denote emissivity of surfaces, $T_{1}$ is temperature of the surface and $T_{2}$ is temperature of the ambient air or the radiating surface, ${ }^{\circ} \mathrm{K}$.

Using Eqs. (2) and (3), it is possible to calculate the temperature on the internal surface of the building envelope. Figure 1 shows the dependence of the temperature factor on the outdoor temperature and on the thermal transmittances of the building envelope (without surface heat transfer coefficients). Due to the higher temperature difference and surface heat transfer coefficients, the building envelope with the same thermal transmittance shows higher temperature factor values at lower outdoor temperatures. The influence of the outdoor temperature is higher on the envelopes with higher thermal transmittance. 


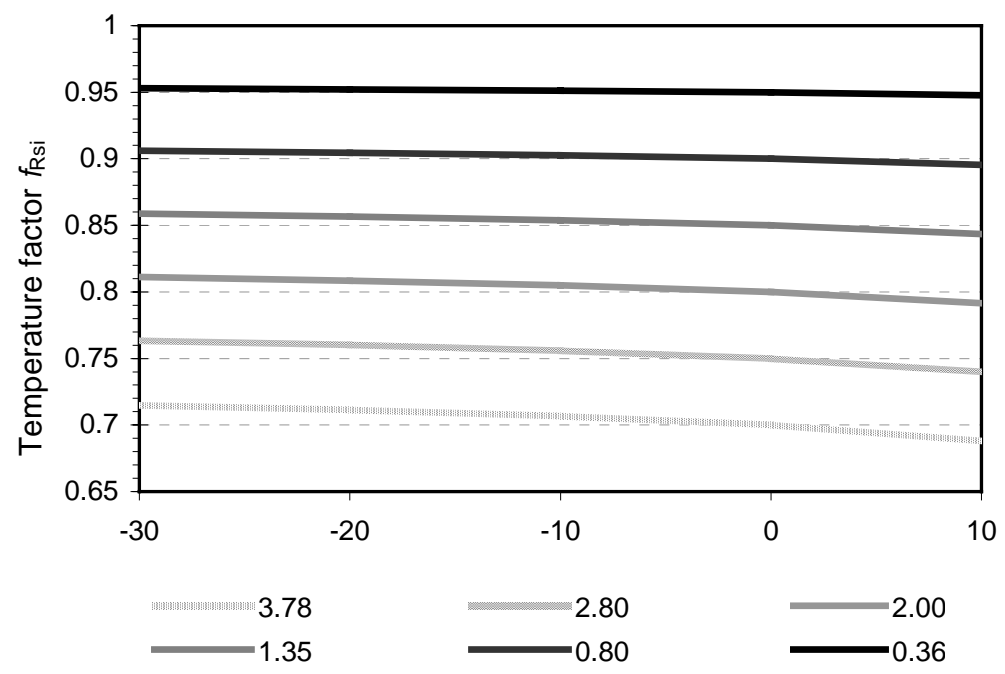

Outdoor temperature $T_{\text {out }},{ }^{\circ} \mathrm{C}$

Fig. 1. The dependence of the temperature factor on the outdoor temperature and on thermal transmittance of the building envelope.

Many countries have set limit values or guidelines for the temperature factor. In Belgium, a technical note $\left[{ }^{4}\right]$ suggests that to evaluate the condensation risk, the temperature factor should be $f_{0.2} \geq 0.7$. Dutch building regulations $\left[{ }^{5}\right]$ set the requirements for the normalized temperature factor $f_{\mathrm{Rsi}} \geq 0.65$ for new residential buildings. In France $\left.{ }^{6}\right]$, the temperature factor limits are linked with the moisture excess in a room. To avoid condensation in rooms with the moisture excess value $2.5-5 \mathrm{~g} / \mathrm{m}^{3}$, the temperature factor should be $f_{\mathrm{Rsi}}>0.52$ (the reference conditions are: $T_{\text {out }}=0^{\circ} \mathrm{C}, R H_{\text {out }}=80 \%$ and $T_{\text {in }}=18^{\circ} \mathrm{C}$ ). On the basis of the indoor temperature $+20^{\circ} \mathrm{C}$ and relative humidity $50 \%$, outdoor temperature $-5^{\circ} \mathrm{C}$, and the highest relative humidity at the surface of the building envelope $80 \%$, the lowest value of the temperature factor 0.7 is determined in the German DIN standard $\left[{ }^{7}\right]$. The Swiss standard $\left[^{8}\right]$ sets the lower limit for the temperature factor 0.75 . In the United Kingdom $\left[{ }^{9}\right]$, to avoid the mould growth and surface condensation in dwellings, $f_{\mathrm{Rsi}} \geq 0.75$. In Finland $\left[{ }^{10}\right]$, recommendations for the minimum value of the temperature factor for new buildings are for floors 0.97 and for walls 0.87. Near the junction of the thermal envelope and separating walls or near the penetration of the thermal envelope, the spot temperature factor value should be more than 0.65 .

In Estonia, no official requirements or guidelines exist for the value of the critical temperature factor. In many guidelines and regulations $\left[{ }^{11-14}\right]$ requirements are formulated to avoid moisture damage, surface condensation and mould growth. In this study, a special climate analysis was conducted to determine the 
design value for the temperature factor for Estonian dwellings by assessing the thermal bridges of the building envelope.

\section{METHODS}

\subsection{Outdoor climate conditions}

The territory of Estonia can be divided into two climatic areas $\left[{ }^{15-18}\right]$ : the coastal area that is directly influenced by the sea and the inland area. The western islands region, the West-Estonian region and the northern coastal region make up the coastal area. The North-Estonian and South-Estonian regions constitute the inland area. The principal territorial differences in climate are due to the adjacent Baltic Sea. The boundary line between the two main climatic areas is shown in Fig. 2.

To determine the critical value of the temperature factor, the outdoor climate was retrieved from six weather stations, covering a 31-year period, from 1970 to 2000. Meteorological stations were chosen according to the climatic areas and the building density of the towns. Tallinn, Kuressaare and Pärnu represent the coastal area and Tartu, Väike-Maarja and Võru the inland area. Tallinn and Tartu have the highest occupancy and building activity. Kuressaare represents the western islands region, while Pärnu is the West-Estonian region in the coastal area. Väike-Maarja represents the North-East Estonia and Võru represents the South-Estonian highland region.

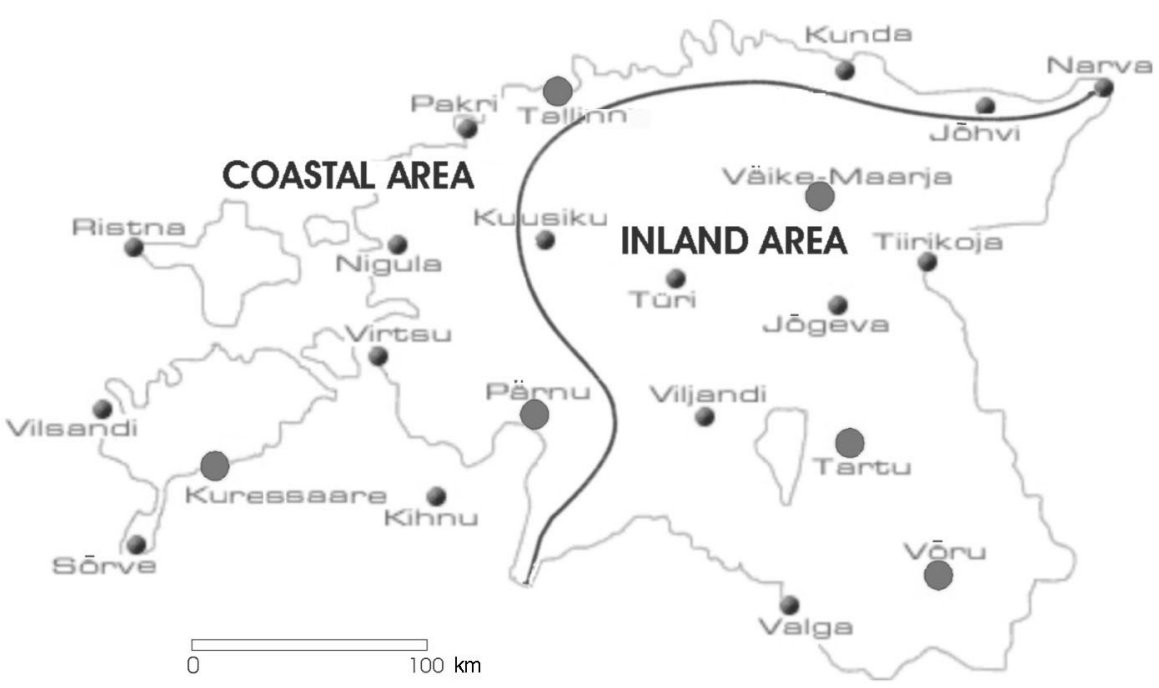

Fig. 2. Climatic areas of the territory of Estonia. Meteorological stations, the data of which were used in this report, are indicated by large dots. 


\subsection{Indoor climate conditions}

The Estonian indoor climate standard $\left[{ }^{14}\right]$ sets the temperature values for three different categories: A, B, C. During summer, the indoor temperature values must range between +22 and $+27^{\circ} \mathrm{C}$ and during winter, between +19 and $+25^{\circ} \mathrm{C}$ in the lowest category C. Because air conditioners are rarely used in detached single-family houses and the heating systems are usually not used during summer, indoor temperatures during summer are not well controllable in detached single-family houses. According to the indoor climate measurements in Estonian dwellings $\left[{ }^{19}\right]$, daily average indoor temperature was almost smooth between +20 and $+22{ }^{\circ} \mathrm{C}$ during the period when the outdoor daily average temperature is between -25 and $+15^{\circ} \mathrm{C}$. By the outdoor temperature of $+15^{\circ} \mathrm{C}$, the indoor temperature started to rise almost linearly from +22 up to $+27^{\circ} \mathrm{C}$ by the outdoor temperature of $+25^{\circ} \mathrm{C}$.

Values of the temperature factor were calculated for two indoor temperature models. First, it was calculated for the average indoor temperature model. Average temperature model with a moisture excess on a $10 \%$ higher critical level corresponded best to the measured indoor $R H$ values on a $10 \%$ higher critical level. Indoor $R H$ is usually the most important factor for mould growth. Temperature on a $10 \%$ lower critical level was $2{ }^{\circ} \mathrm{C}$ lower than the average temperature. There were also rooms where the temperature was on average $2^{\circ} \mathrm{C}$ lower than the average temperature of all the houses. Therefore, factor analysis of the critical temperature was done also with the indoor temperature on a $10 \%$ lower critical level.

The indoor humidity level depends mainly on the moisture production, the air change rate and the outdoor humidity. The indoor climate standard $\left[{ }^{14}\right]$ sets the limit values also for the relative humidity: from 25 to $45 \%$ during winter and from 30 to $70 \%$ during summer. Because in detached houses, as a rule, the indoor air is neither humidified nor dried, in this study, the internal moisture excess, $\Delta v$ (difference in the air water vapour content of the indoors and outdoors air), was used to calculate the indoor humidity. According to the indoor climate measurements in Estonian detached houses (average occupancy $46 \mathrm{~m}^{2} / \mathrm{pers}$, average ventilation air change rate 0.41 ach $\left(13.3 \mathrm{l} /(\mathrm{s} \cdot\right.$ pers $)$ and $\left.0.28 \mathrm{l} /\left(\mathrm{s} \cdot \mathrm{m}^{2}\right)\right)$, a moisture excess on a $10 \%$ higher level in houses with low occupancy during the cold period $\left(T_{\mathrm{e}} \leq+5^{\circ} \mathrm{C}\right)$ was $+4 \mathrm{~g} / \mathrm{m}^{3}$, during the warm period $\left(T_{\mathrm{e}} \geq+15^{\circ} \mathrm{C}\right)$ close to $+1.5 \mathrm{~g} / \mathrm{m}^{3}$ and it decreased between these levels linearly. With a $1 \mathrm{~g} / \mathrm{m}^{3}$ change in the moisture excess during the cold period, a $0.5 \mathrm{~g} / \mathrm{m}^{3}$ change during the warm period was observed.

The critical temperature factor was calculated for two different indoor humidity levels. The moisture excess during the cold period was taken $+4 \mathrm{~g} / \mathrm{m}^{3}$ and during the warm period $+1.5 \mathrm{~g} / \mathrm{m}^{3}$, that represents a $10 \%$ higher humidity load level in houses with low occupancy. According to statistics, the average living area per person of the overall Estonian housing stock is $28 \mathrm{~m}^{2} /$ pers. Therefore in apartments, where the living density is higher, more severe design 


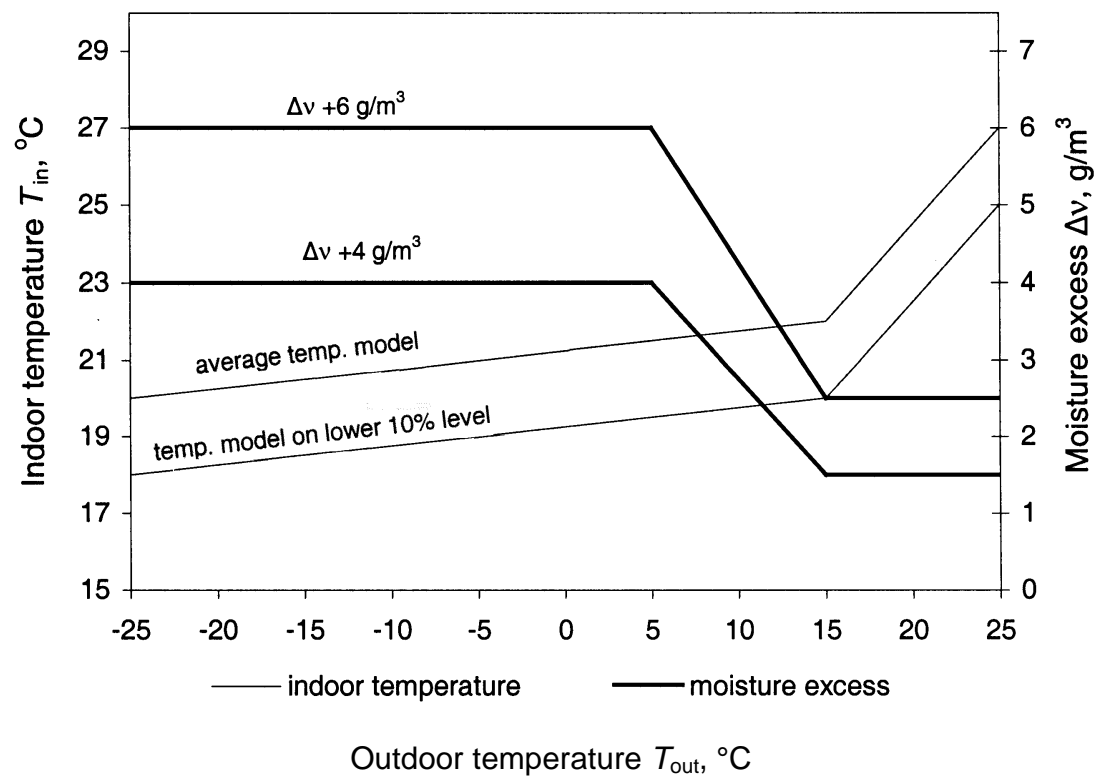

Fig. 3. The indoor climate models used to determine the critical value of the temperature factor.

loads should be taken into account. The moisture excess value $+6 \mathrm{~g} / \mathrm{m}^{3}$ during the cold period and $+2 \mathrm{~g} / \mathrm{m}^{3}$ during the warm period were chosen for apartments with higher living density. As suggested in $\left[^{2}\right]$, the values of the moisture excess are multiplied by 1.1. Figure 3 shows the indoor climate models used to select the critical value of the temperature factor.

\subsection{Method for selecting the critical value of the temperature factor}

The values of the critical temperature factor $f_{\text {Rsi }}$ were selected to avoid the mould growth and surface condensation. To avoid the mould growth due to the outdoor temperature and humidity, the average monthly absolute indoor humidity was calculated using the internal moisture excess models (Fig. 3). With the maximum acceptable $R H$ at the thermal envelope surface $80 \%$, the maximum acceptable absolute humidity was calculated. Using it, the minimum acceptable surface temperature was calculated. Using this minimum acceptable surface temperature, the outdoor temperature and the indoor temperature, the minimum temperature factor was calculated according to Eq. (1). The calculation procedure employed for selecting the critical temperature factor to avoid surface condensation, was the same, only the daily average climate values and the maximum acceptable $R H$ at the surface of the envelopes, $R H_{\mathrm{si}}=100 \%$ were used. 
For each location, each year and each month, the maximum temperature factor was calculated. To determine the critical value for the temperature factor, a $10 \%$ higher level was used, as is suggested for building physics calculations $\left[{ }^{20}\right]$. It means that $10 \%$ of the monthly maximum values would be defined as critical, whereas the remaining $90 \%$ of the monthly maximum values would fall below the critical temperature factor value. The determined design values of the temperature factor were rounded.

\section{RESULTS}

Figures 4 and 5 show the influence of the indoor temperature and of the moisture excess (marked value during the cold period) on the temperature factor limits to avoid the mould growth and surface condensation. These figures show a $10 \%$ higher level from the six stations during the 31-year period.

To avoid the mould growth on the thermal bridges, the design value of the temperature factor in dwellings should be $f_{\mathrm{Rsi}} \geq 0.80$. According to the surface condensation, the limit value for the temperature factor is $f_{\mathrm{Rsi}} \geq 0.70$. If it is

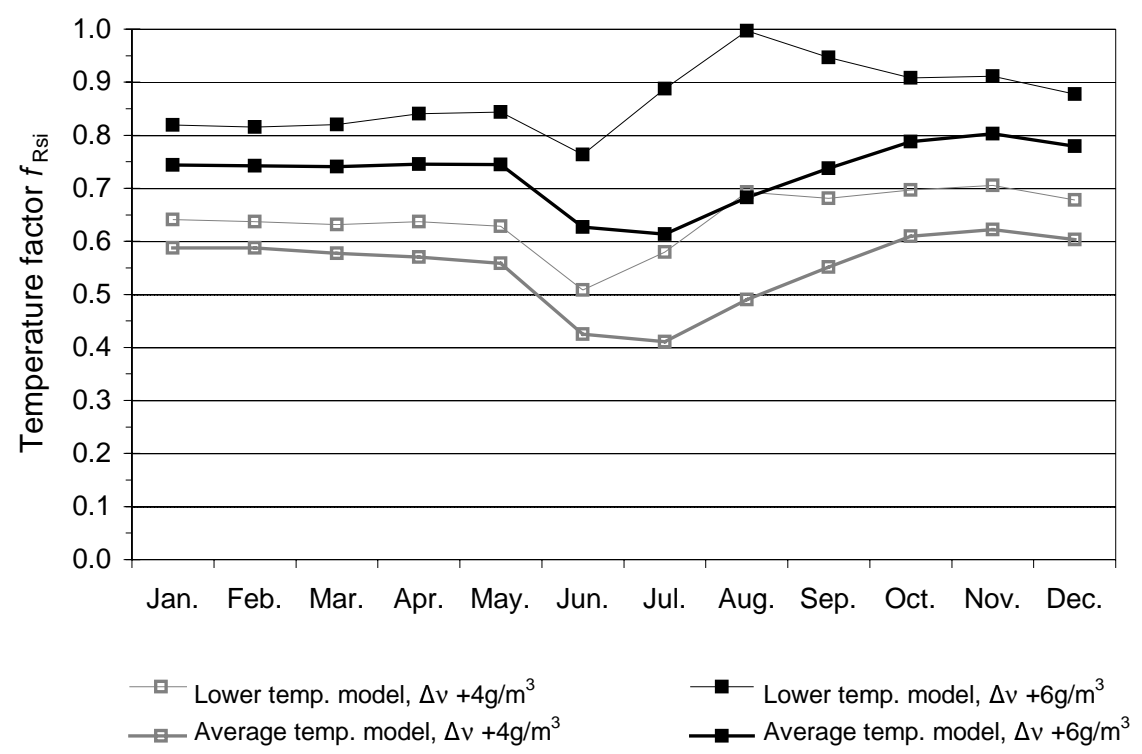

Fig. 4. Dependence of the critical temperature factor on the calculation models, calculated according to the mould growth criterion. 


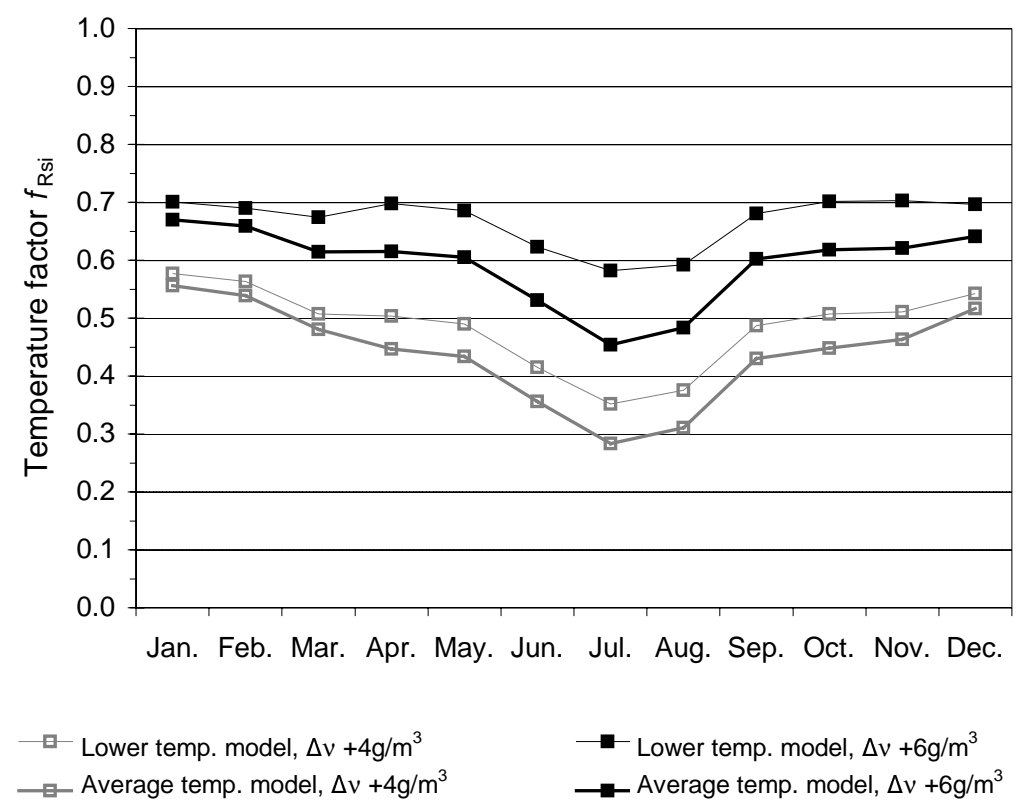

Fig. 5. Dependence of the critical temperature factor on the calculation models, calculated according to the surface condensation criterion.

otherwise indicated, lower indoor humidity conditions (based on the designer's investigation of the indoor hygrothermal loads, the ventilation system or lower occupancy), the temperature factor for avoiding the mould growth should be $f_{\mathrm{Rsi}} \geq 0.65$ and to avoid condensation $f_{\mathrm{Rsi}} \geq 0.55$. In the most critical cases (high indoor humidity conditions, low room temperature), mould growth is possible even at well-insulated surfaces (Fig. 4). It proves the importance of the role of ventilation and heating in the regulation of the humidity level in rooms with high moisture production. The temperature factor $f_{\text {Rsi }} \geq 0.70$ is a suitable value for avoiding condensation also in the case of the lower temperature model.

In the following, the limit values for indoor relative humidity in relation to surface condensation and mould growth are calculated. The aim was to find the highest level of indoor relative humidity by which neither the surface condensation nor mould growth occurs. The highest relative indoor humidity was selected from the minimum values for each outdoor temperature calculated using the temperature factor 0.80 and the highest relative humidity at the surface of the building envelope $R H_{\mathrm{si}}=80 \%$ (mould growth criterion) or $f_{\mathrm{Rsi}}=0.70$ and $R H_{\mathrm{si}}=100 \%$ (condensation criterion). For lower indoor humidity conditions, the highest indoor relative humidity was calculated using the temperature factor 0.65 and the highest relative humidity at the surface of the building envelope $80 \%$ (mould growth criterion) or $f_{\mathrm{Rsi}}=0.55$ and $R H_{\mathrm{si}}=100 \%$ (condensation criterion). Figure 6 shows the limiting curves for the indoor relative humidity for 


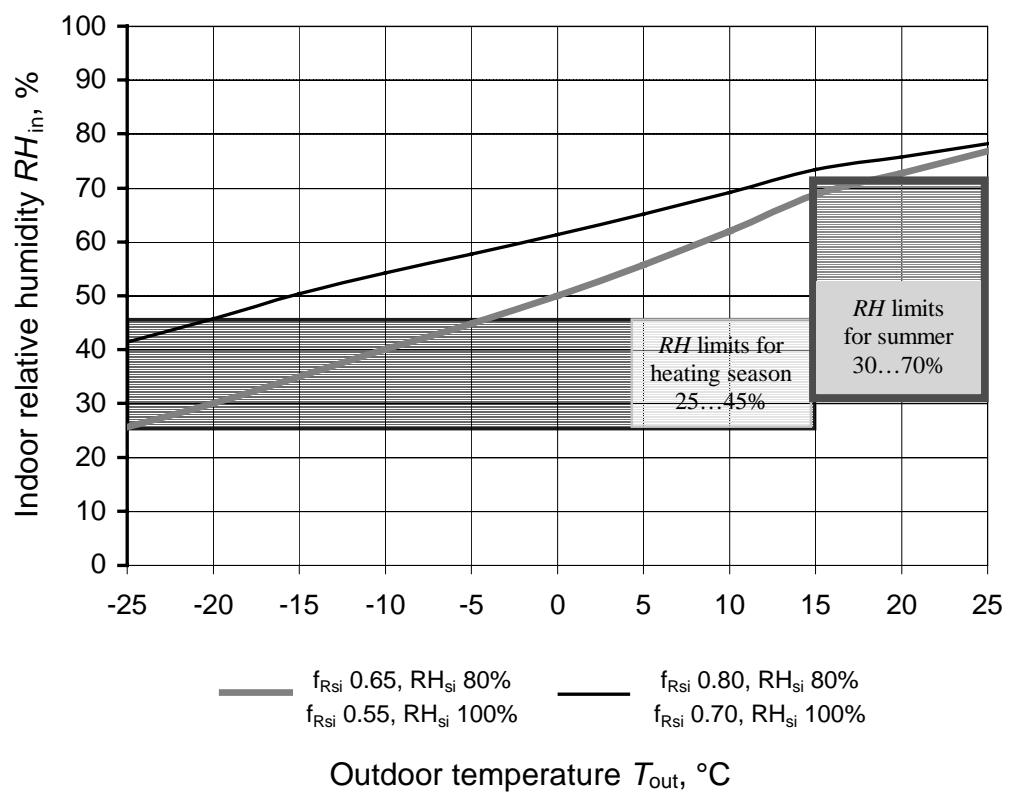

Fig. 6. Limiting curves for indoor $R H$ to avoid the risk of mould growth and surface condensation according to determined design values for the temperature factor.

the average indoor temperature model (Fig. 3). Design values of the temperature factor for a lower humidity load level do not cover standardized indoor relative humidity values $\left[{ }^{14}\right]$. Therefore, these lower values of the temperature factor are allowed to be used only if the lower indoor humidity conditions are clearly defined and argued.

\section{DISCUSSION}

Temperature factors were calculated for two different indoor humidity and temperature conditions. The critical relative humidity $R H_{\mathrm{si}}=80 \%$ was used for the mould growth criterion. The critical $R H$ for mould growth depends also on many other factors. According to Hukka and Viitanen $\left[{ }^{21}\right]$, at the temperature $T_{\mathrm{si}}<20^{\circ} \mathrm{C}$, a mathematical relationship between the temperature and the critical $R H$ for mould growth exists. By using this dependence, we obtain an about $3 \%$ lower value of the temperature factor. Nevertheless, constant $R H$ was used for safety reasons.

The determined critical temperature factors can be directly used for thermal bridge investigations (e.g. with infrared thermography) in real buildings. Indoor, outdoor and internal surface temperatures can all be directly measured. In the design process, to calculate the correct internal surface temperature, we should know the thermal resistance $R_{\mathrm{si}}$ of the internal surface. The internal surface 
resistance depends on the convection and radiation coefficients: on the air movement in the room, on the air and surface temperature distribution in the room and on surface material properties. The thermal resistance of the surface may vary a great deal. High values can be found in the case of significant thermal shielding by furniture and low values, for example, in a room with only external walls and a convective heating system. To calculate the correct internal surface temperature in the design process, $R_{\mathrm{si}}$ should be determined using the thermal model of the room, taking into account the thermal resistances of the surrounding envelope, temperature of the environment, the distribution of the air temperature in the room and its geometry. If that information is not available, simplified methods or the values recommended by $\left[{ }^{22}\right]$ (in most of the cases considered as safe values) can be used.

To determine the repair works, based on thermographic studies, defective constructions in dwellings with a temperature factor $f_{\mathrm{Rsi}}<0.65$ should be repaired immediately. Envelopes with the temperature factor $f_{\mathrm{Rsi}}<0.80$ may be classified as satisfactory from the point of view of surface condensation and mould growth and have no need for corrective action. To assess the risk and to determine the need for envelope repairs for the temperature factor $0.65<f_{\mathrm{Rsi}}<0.80$, different aspects should be taken into account: hygrothermal behaviour of the building envelope, parameters of indoor climate, thermal comfort, purpose of use of the building, economic aspects (repair costs, energy consumption, payback period), service life of the building, etc.

\section{CONCLUSIONS}

To determine and classify thermal bridges, the acceptable temperature factor was calculated for the Estonian climate (during 31 years from six different locations) and the critical indoor hygrothermal load.

In dwellings with a moisture excess $+6 \mathrm{~g} / \mathrm{m}^{3}$ during the cold period and $+2.5 \mathrm{~g} / \mathrm{m}^{3}$ during the warm period (commonly apartments of high occupancy or low ventilation), to avoid the mould growth on the thermal bridges, the spot temperature factor should be $f_{\mathrm{Rsi}} \geq 0.80$. According to the surface condensation, the limit value for the temperature factor is $f_{\text {Rsi }} \geq 0.70$. In dwellings with a moisture excess $+4 \mathrm{~g} / \mathrm{m}^{3}$ during the cold period and $+1.5 \mathrm{~g} / \mathrm{m}^{3}$ during the warm period (commonly detached houses of low occupancy and normal ventilation), to avoid the mould growth, the temperature factor should be $f_{\text {Rsi }} \geq 0.65$ and to avoid surface condensation $f_{\text {Rsi }} \geq 0.55$. In the most critical cases (high indoor humidity conditions, low room temperature), mould growth is possible even on well-insulated surfaces. It proves the importance of the role of ventilation to regulate moisture levels in rooms with a high moisture production. 


\section{ACKNOWLEDGEMENTS}

This study has been financed by Estonian Science Foundation (grant No. 5654). The author wish to thank the Estonian Meteorological and Hydrological Institute for the climatic data, which made this work possible.

\section{REFERENCES}

1. Hens, H. (ed.). Condensation and Energy, Guidelines and Practice. Vol. 2, Annex 14, International Energy Agency, KU Leuven, 1990.

2. EN ISO 13788:2001. Hygrothermal performance of building components and building elements - Internal surface temperature to avoid critical surface humidity and interstitial condensation - Calculation methods. International Organization for Standardization, Brussels, 2001.

3. Hagentoft, C.-E. Introduction to Building Physics. Studentlitteratur, Lund, 2001.

4. Uyttenbroeck, J. and Carpentier, G. Vochthuishouding in gebouwen. Wissenschaftliches und Technisches Bauzentrum. Technische voorlichtingen 153, Brussels, 1984.

5. NEN 2778:1991. Vochtwering in gebouwen, Bepalingsmethoden. Nederlands Normalisatieinstituut, Delft, 1991.

6. Berthier, J. Diffusion de vapeur au travers des parois - Condensations. C.S.T.B. - REEF Sciences du Bâtiment, Vol. II, Paris, 1980.

7. DIN 4108-2:2001-03. Wärmeschutz und Energie-Einsparung in Gebäuden. Teil 2: Mindestanforderungen an den Wärmeschutz. Deutsches Institut für Normung, Berlin, 2001.

8. SIA-180:1999. Wärme- und Feuchteschutz im Hochbau. Schweizerische Ingenieur- und Architektenverein, Zürich, 1999.

9. BRE IP 17/01. Assessing the Effects of Thermal Bridging at Junctions and Around Openings. BRE, Building Research Establishment Ltd, Garston, 2001.

10. Asumisterveysohje. Sosiaali- ja terveysministeriön oppaita 2003:1, Sosiaali- ja terveysministeriö, Helsinki, 2003.

11. Eluruumidele esitatavad nõuded. Kehtestatud Vabariigi Valitsuse 26.01.1999. a määrusega nr. 38. Riigi Teataja I, 1999, 9, 38.

12. Ehitusseadus. Vastu võetud 15.05.2002. a seadusega. Riigi Teataja I, 2002, 47, 297.

13. EVS 837-1:2003. "Piirdetarindid. Osa 1: Üldnõuded”. Eesti Standardikeskus, Tallinn, 2003.

14. EVS 839:2003. "Sisekliima". Eesti Standardikeskus, Tallinn, 2003.

15. Kirde, K. Andmeid Eesti kliimast. Tartu Ülikooli Meteoroloogia Observatooriumi Teaduslikud Väljaanded, 1939, No. 3.

16. Kirde, K. Kliima-valdkonnad Eestis. Tartu Ülikooli Meteoroloogia Observatooriumi Teaduslikud Väljaanded, 1943, No. 5.

17. Raik, A. Eesti klimaatilisest rajoneerimisest. Eesti Loodus, 1967, 2, 65-70.

18. Karing, P. Õhutemperatuur Eestis. Valgus, Tallinn, 1992.

19. Kalamees, T. Indoor hygrothermal loads in Estonian dwellings. In Proc. 4th European Conference on Energy Performance and Indoor Climate in Buildings. Lyon, 2006.

20. Sanders, C. (ed.). Heat, Air and Moisture Transfer Through New and Retrofitted Insulated Envelope Parts, Environmental Conditions, Task 2, Annex 24, International Energy Agency, KU Leuven, 1996.

21. Hukka, A. and Viitanen, H. A mathematical model of mould growth on wooden material. Wood Sci. Technol., 1999, 33, 475-485.

22. EN ISO 10211-1:1995. Thermal bridges in building construction - Heat flows and surface temperatures - Part 1: General calculation methods. International Organization for Standardization, Brussels, 1995. 


\title{
Kriitilised temperatuuriindeksid Eesti elamute külmasildade hindamiseks
}

\author{
Targo Kalamees
}

On määratud temperatuuriindeksi projekteerimisväärtused külmasildade hindamiseks Eesti elamute projekteerimisel ja ekspertiiside tegemisel. On kasutatud kuue linna 31 aasta (1970-2000) kliimaandmeid. Sisekliima osas on kasutatud Eesti väikemajade sisekliimauuringu mõõtetulemusi. Temperatuuriindeksi määramise kriteeriumiks on hallituse tekke ja niiskuse kondenseerumise ärahoidmine. Et vältida hallituse tekke riski eluruumides, peab temperatuuriindeks olema suurem kui 0,8 ning niiskuse kondenseerumise vältimiseks suurem kui 0,7. 